\title{
Landslide hazard, monitoring and conservation strategy for the safeguard of Vardzia Byzantine monastery complex, Georgia
}

C. Margottini, N. Antidze, J. Corominas, G. B. Crosta, P. Frattini, G. Gigli, D. Giordan, I. Iwasaky, G. Lollino, A. Manconi, P. Marinos, C. Scavia, A. Sonnessa, D. Spizzichino, N. Vacheishvili

\begin{abstract}
This paper reports preliminary results of a feasibility project developed in cooperation with National Agency for Cultural Heritage Preservation of Georgia, and aimed at envisaging the stability conditions of the Vardzia monastery slope (rupestrian city cave in the south-western Georgia). The aim is the implementation of a low-impact monitoring system together with long-term mitigation/conservation policies. A field analysis was conducted to reconstruct geometry of the rocky cliff, characteristics of discontinuities, main failure modes, and volume of potential unstable blocks and geomechanical parameters. Instability processes are the combination of causative factors such as the following: lithology, frequency and orientation of discontinuities, slope orientation, physical and mechanical characteristics of slope-forming materials, and morphological and hydrological boundary conditions. The combined adoption of different survey techniques (e.g., 3D laser scanner, ground-based radar interferometry) could be the best solution in the interdisciplinary field of cultural heritage preservation policies. The collected data will be the basis for future activities to be completed in collaboration with local authorities for a complete hazard and risk characterization for the monastery site and the development of an early warning system to allow safe exploitation for touristic activities and for historical site preservation.
\end{abstract}

Keywords Planar slide and wedge failure . Rock fall . Kinematic analysis . Terrestrial laser scanner . Mitigation strategy . Vardzia (Georgia)

\section{Introduction}

The rock-cut city of Vardzia is a cave monastery site in southwestern Georgia, excavated from the slopes of the Erusheti mountain on the left bank of the Mtkhvari river. The main period of construction was the second half of the twelfth century. The caves stretch along the cliff for some $800 \mathrm{~m}$ and up to $50 \mathrm{~m}$ within the rocky wall (Fig. 1). The monastery consists of more than 600 hidden rooms spread over 13 floors, which made possible to protect the monastery from the Mongol domination. The main lower site was carved from the cliff central layer of volcanic and pyroclastic rocks (Gillespie and Styles 1999) at an elevation of $1300 \mathrm{~m}$ above sea level. The cave city included a church, a royal hall, and a complex irrigation system. The earthquake that struck Samstkhe in 1283 AD destroyed about two thirds of the city cave and the irrigation system, exposing the majority of the rooms to view outside. The site was largely abandoned after the Ottoman takeover in the sixteenth century. Now part of a state heritage reserve, the site has been submitted for future inscription on the UNESCO World Heritage List. The site is by the time affected by frequent slope instability processes along the entire volcanic tuff façade of the slope. Due to this phenomena, the National Agency for Cultural Heritage Preservation of Georgia (NACHPG) has promoted, with the support of ISPRA, a landslide hazard assessment for the entire area through rock mechanics characterization, geotechnical engineering survey, geo- 
structural and kinematic analysis, slope stability model, 3D laser scanner acquisitions and elaborations, and a real-time monitoring system (GB_Radar interferometry) for the identification of deformation path of the most hazardous areas.

The present work, summarizes both the main results of the studies carried out from December 2011 to December 2012, and the main output coming from the International workshop on "Landslide hazard assessment and monitoring sustainable techniques for the safeguard of Vardzia Monastery site” (Georgia 16- 19, October 2012) with its technical visit and expert meetings. The workshop has been promoted within the frame of the ICL network on Landslide and Cultural and Natural Heritage. On this occasion, international experts in the field of geological and geotechnical problems linked with the preservation of historical and archeological heritage were invited to propose and define short and long-term strategies for the area of Vardzia. They could deal directly in the area with the problems, share views and knowledge with local technicians (capacity building actions), and trace hypothesis of intervention and implementation of studies for the future management policies for the area. The synthesis of this experience and its schema and methodological approach is described later in this paper.

\section{Collected data}

Laser scanning survey

The rock-cut monastery city of Vardzia is located in the southwestern Georgia, near Akhaltsikhe close to the Turkish border, facing southwards onto the Mtkhvari river valley. As a preliminary data base, existing topographical and geological maps have been collected and elaborated through a GIS platform in order to implement a geodatabase to store all the information useful for future analyses.

In order to carry out a site-scale specific analysis and to support the monitoring system activities, a detailed geodetic 3D laser scanning survey has been performed and implemented during the May 2012 field mission. The geodetic surveying was aimed at the three-dimensional (3D) reconstruction of the cave monastery and collection of data for future potential slope stability analysis of the whole cave complex. All 3D data were collected in a local reference frame by means of a terrestrial high-resolution laser scanner (TLS), and then georeferenced by using high-precision dual-frequency geodetic GNSS receivers (Margottini et al. 2009). 


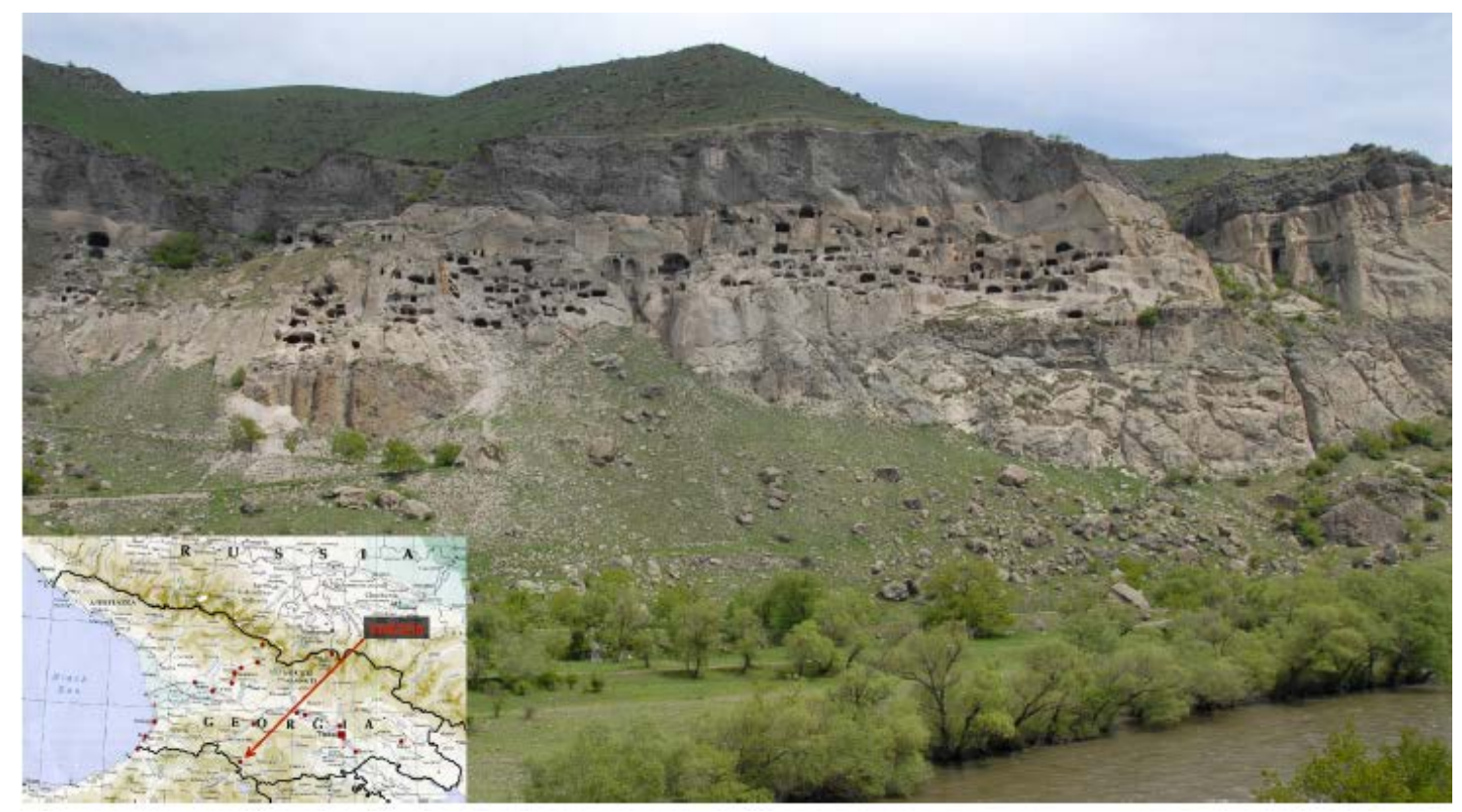

Fig. 1 The rock-cut city of Vardzia (Georgia)

Surveying activities at the Vardzia site were performed using a topographical Riegl Z210i laser scanner both for measuring the 3D coordinates of the models and acquiring the RGB information linked to the point clouds. Ten TLS scans were acquired, in order to exactly reconstruct the topography of the site (Fig. 2), from two different scan positions by applying the multi-scanning technique (Baldo et al. 2009). Average spatial resolution ranges from $10 \times 10 \mathrm{~cm}$ up to some meters, depending on the distance between the laser and the object. Purpose-built targets were used to link the scans together and to build up a high-resolution 3D model of the cave monastery. The final model consists of a point cloud made of about $8,000,000$ points from which a DTM with a $1 \times 1 \mathrm{~m}$ cell size has been derived.

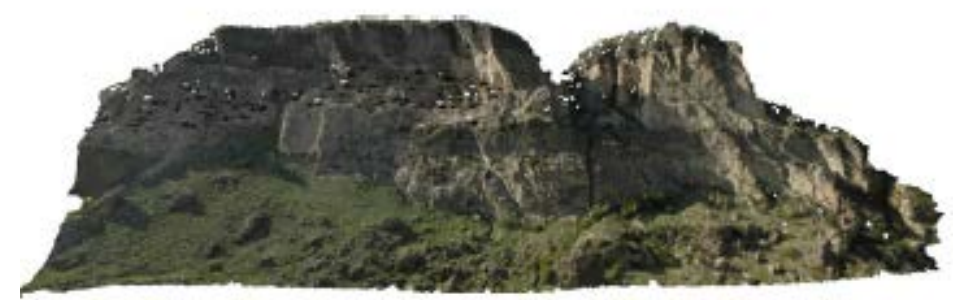

Fig. 2 Textured 3D model of the cave monastery of Vardzia from TLS techniques

\section{Geomorphology and geology}

Vardzia is an excellent example of the cultural landscape (Margottini and Spizzichino. 2009) in which human activities (e.g., excavation, construction, and implementation of the cave monastery, painting), natural, geological, and geomorphological processes, are strictly connected and interdependent. Often, lithology (e.g., soft rock easy to excavate), 
geomorphological processes (e.g. landsliding, erosion and weathering), beautiful and impressive landscapes, and inaccessibility (settlement easier to defend and protect) have been the main elements in the history of humanity concerning the choice for the realization of towns, monuments, religious structures, and defense works (Margottini and Spizzichino 2014). The geomorphological aspect of the Vardzia monastery is the result of various long- and short-term factors (natural and human) that affected this part of Georgia. Active tectonics related to the Caucasian System jointly with the volcanic activity had a big influence on the present day morphology of the surrounding territory. Vardzia slopes are the final result of local seismicity, different volcaniclastic and pyroclastic falls, erosion, and deposition cycles of the Mtkhvari river. The entire rock wall has a length of about $800 \mathrm{~m}$ for a height of $130 \mathrm{~m}$ with a general $\mathrm{EW}$ orientation. The slopes, as a general rule, present a rupestrian aspect, mainly stratified and alternatively massive. Nevertheless, discontinuities of various types are present, potentially related to the following: cooling phase after volcanic activity (vertical), tectonic activity (faults, minor joints, mainly sub-vertical), and geomorphological activity (stress release caused by valley incision). Sub-vertical and high-angle dipping joints intersecting horizontal bedding (layers of different pyroclastics falls) are quite frequent in the area and have been observed during field investigation (Ershov et al. 1999). This situation causes potential falls, sliding, and toppling of blocks, whose type, dimension, and kinematics depend on local orientation, mechanical properties of pyroclastic layers, spacing, and persistence of joints.

The Vardzia monastery is entirely cut and carved in volcanic and pyroclastic rocks (Gillespie and Styles 1999) formations (upper Moitsen-lower Moitsen); see Fig. 3 (Gudjabidze and Gamkrelidze 2003).

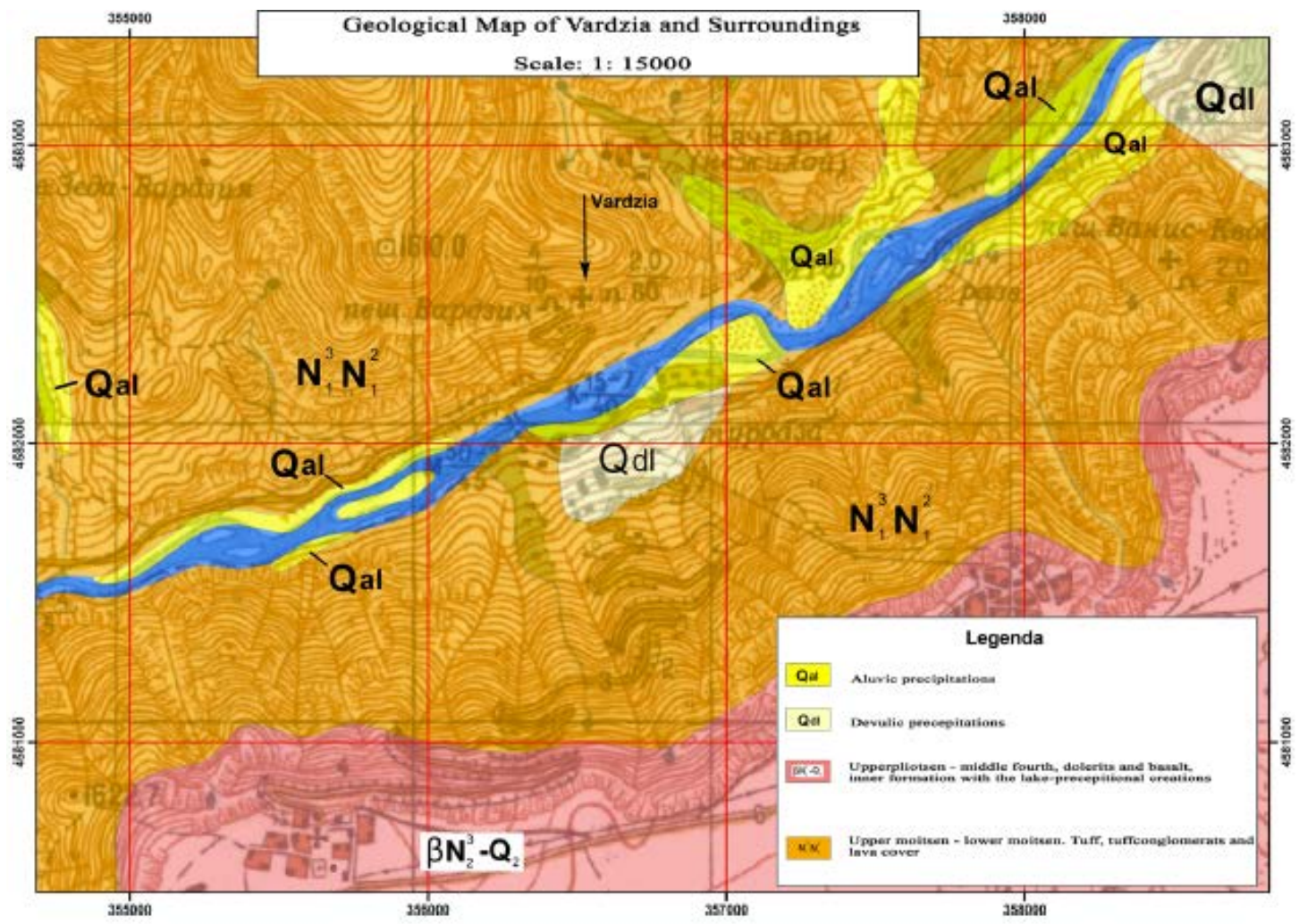

Fig. 3 Geological map of Vardzia at 1:15,000 scale (kindly provided by NACHPG) 
A representative lithologic cross section of the slope has been accomplished during the last field mission (Fig. 4). The entire geologic sequence is the final result of several volcaniclastic and pyroclastic falls, characterized by different explosion dynamics and chemical lava compositions. Concerning the structural setting, at the slope scale, it is possible to define two main discontinuity systems, the first (sub vertical) due to cooling of the volcaniclasti sequence and a second one (locally parallel to the slope face) mainly due to stress release caused by the valley erosion. The spacing decreases at depth moving within the rock mass as visible through some minor tunnels. Probably, both layers number 1 and number 4 (Fig. 4) can be further subdivided into sub-layers. The joint sets observed and present in layer 2 also affect layer 1 . The boundary between the different volcaniclastic levels is not always clearly marked but they are all sub-parallel according to the style of deposition. Further analyses are needed (thin section and X-ray diffractometric analysis), in order to classify the different types of rock from a petrographical point of view.

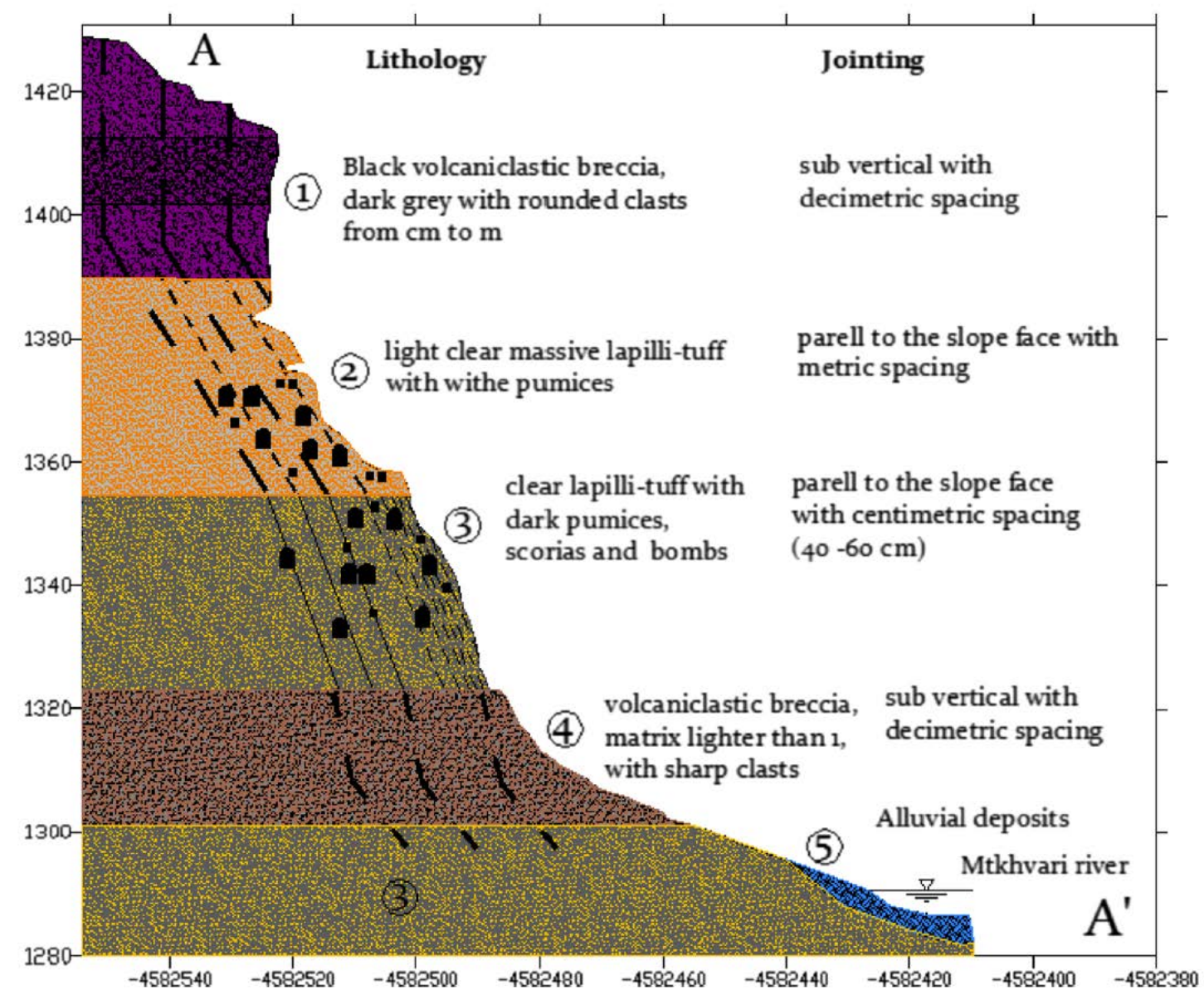

Fig. 4 Litostratigraphic cross section of the Vardzia rocky cliff

$\underline{\text { Geo-mechanical parameters }}$

Geomechanical characteristics of the volcaniclastic and pyroclastic rocks outcropping in the study area have been determined by means of geotechnical field surveys and 
laboratory tests, on rock blocks. The following activities have been carried out during the 2011 and 2012 field survey:

- Geomechanical rock mass classification, in order to derive the main geomechanical characteristics and indexes (e.g. RMR, GSI, Q system)

- Natural unit weight

- Tilt test

- Schmidt-hammer test on joint surfaces and intact rock block for in situ analysis of UCS (unconfined compressive strength)

- Point load test to provide UCS data from sampled blocks (ISRM 1978, 1981)

- Strength and deformation parameters from scientific and technical literature (Hoek 2007; Barton 1973; ISRM 1981) as well as from local technical reports

The preliminary site investigations provided the results summarizedin Table 1 .

\begin{tabular}{|l|c|l|l|c|}
\hline Lithology & $\begin{array}{l}\text { Natural unit } \\
\text { weight }\left(\mathrm{kN} / \mathrm{m}^{3}\right)\end{array}$ & $\begin{array}{l}\text { UCS from Schmidt- } \\
\text { hammer } \\
\text { test (MPa) }\end{array}$ & $\begin{array}{l}\text { Basic joint friction } \\
\left.\text { angle ( } \phi^{\circ}\right) \text { (from tilt } \\
\text { test) }\end{array}$ & $\begin{array}{l}\text { UCS from point } \\
\text { load test (MPa }\end{array}$ \\
\hline $\begin{array}{l}\text { Layer 1, black volcanic } \\
\text { breccia }\end{array}$ & 18.9 & 19 & & 14.8 \\
\hline $\begin{array}{l}\text { Layer 2, light massive } \\
\text { tuff }\end{array}$ & 17.5 & 17 & $22^{\circ}-32^{\circ}$ & 9.6 \\
\hline $\begin{array}{l}\text { Layer 3, whitish tuff } \\
\text { with dark pumices }\end{array}$ & 15.1 & 15 & $22^{\circ}-32^{\circ}$ & 10.8 \\
\hline
\end{tabular}

Table 1 Main geomechanical parameters for the Vardzia rocks

Lithologies are quite weak (Lembo Fazio et al. 1984), as usual in areas where human being realized important underground settlements. Uniaxial compressive strength and bulk density of the different layers range between 10 and15 MPa and 15 and $19 \mathrm{kN} / \mathrm{m} 3$, respectively. These values are comparable to those described for similar lithologies

(Moon 1993; Tuğrul 2004; Binal 2009; Del Potro and Hürlimann 2009; RodríguezLosada et al. 2009; Pola et al. 2012), and they will be defined in more detail by means of future testing campaigns.

\section{$\underline{\text { Geo-structural analysis }}$}

The mechanical behavior of rocks is generally controlled by the conditions under which deformation takes place and by the inherent rock properties (Turner and Schuster 1996). Stress conditions of Vardzia monastery slope promoted different types of discontinuities in the volcaniclastic igneous rocks (Mitchell and Westaway 1999). This is due to the stress-strain behavior (e.g., lateral unloading due to valley erosion coupled with tectonic stress and cooling of the pyroclastics falls) and to the typical petrographical and physical properties of the soft rocks (e.g., chemical and mineralogical composition, grain size, shape, thickness, homogeneity, porosity, permeability, type of cement). The presence of brittle volcanic and pyroclastic rocks in the area, as a general rule, promotes blocky rock masses due to high frequency of discontinuities of various origins (Gamkrelidze 1986). A geomechanical characterization of discontinuities has been done along the entire study area in order to describe the structural setting of the area and recognize eventual master joints. Rock weathering, slope degradation, and instability in the area are the result of different structural combinations of the main joint sets 
(Spizzichino et al. 2009). Our analyses, although only a preliminary and not exhaustive discontinuity survey was performed over the whole area, allowed to characterize some relevant slope sector in terms of discontinuity orientation. All collected data have been analyzed (DIPS ${ }^{\circledR}$ Rocscience software). The rock mass strength has been observed to depend on the density, nature, and extent of fracture and rock strength (i.e., lower within the black volcanic breccia, higher within whitish tuff and lapilli tuff). The stereoplots of Fig. 5 show that the major joint systems are steeply dipping $\left(70^{\circ}\right)$ towards SE (dip direction $140^{\circ}-165^{\circ}$ ). A preliminary kinematic analysis focused on the identification of possible instability modes has been performed for sliding (planar, wedge) and toppling (direct and flexural) phenomena. The main results are also shown in the stereoplots of Fig. 5.
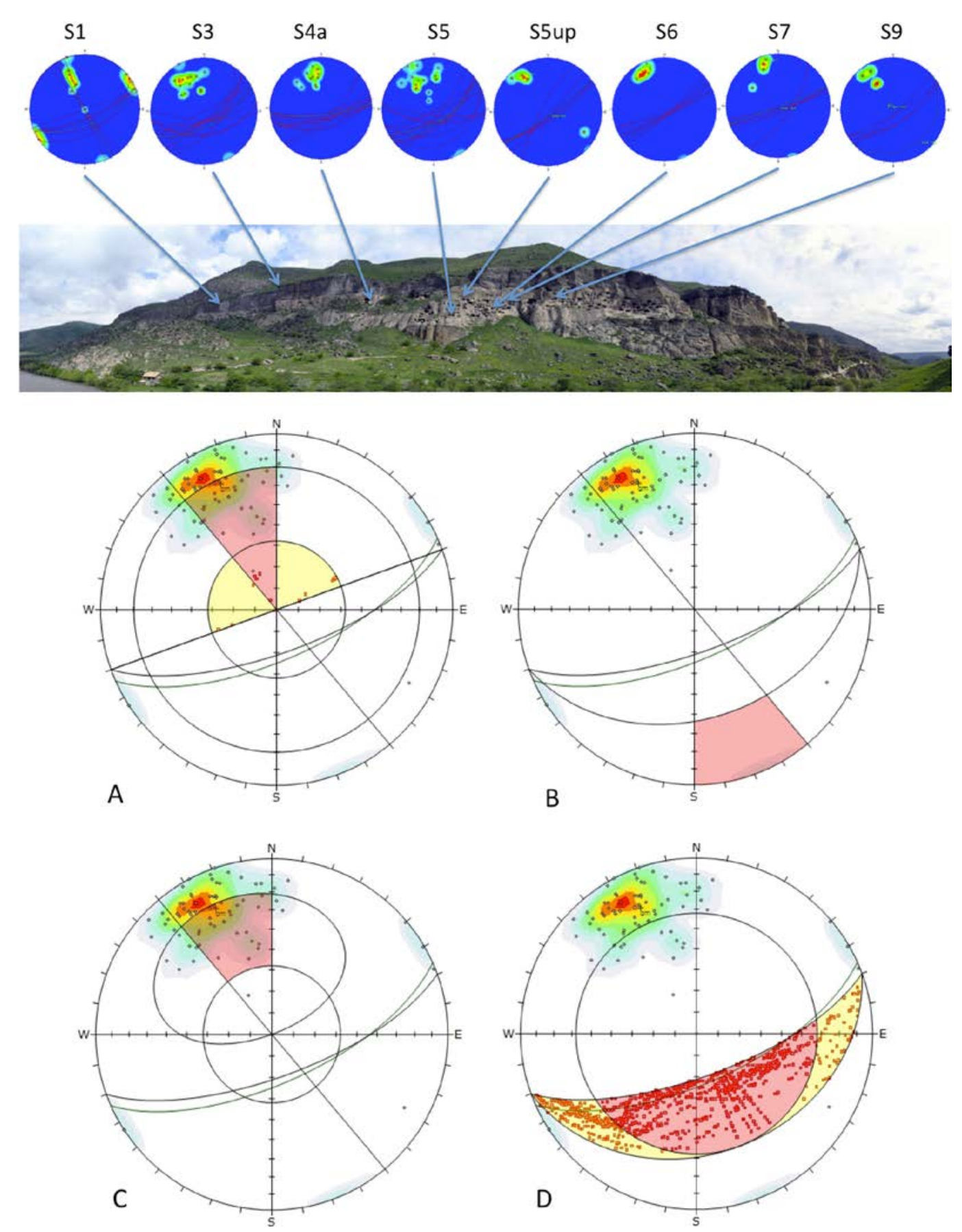
Fig. 5 Stereoplots of joint dip measurements from the Vardzia monastery area (left) and global kinematic analyses (right): a direct toppling $(0.42 \%$ of total planes), b flexural toppling (no critical planes), c planar sliding (32.88\%of total planes), and d wedge failure (44.59 \% of total planes)

\section{$\underline{\text { Slope stability and evolution }}$}

The site of Vardzia is affected by many examples of slope instabilities such as rock fall, topple, and rock slide, with volumes ranging from a few cubic meters to the thousands (WP/WLI 1993). Many phenomena also occurred in recent years, such as in May 1968 when a huge protective wall was constructed just above the main church, to support the rock cliff instability, till the very recent rock slide of spring 2011.

Following the general scheme of the cross section defined in Fig. 4 and with the aim to provide a preliminary assessment according to slope failure type and processes affecting the entire rocky cliff (from top to bottom), most failures can be classified into various categories (Cruden 1991; Cruden and Varnes 1996), depending on the combination of the main joint sets and the geomechanical and geo-structural conditions of the different layers. The only exception is the large roto-translational rock slide, potentially affecting both layers 1, 2, and 3. With reference to the different levels of Fig. 4, the main rock slope failures can be classified as follows and displayed in Fig. 6.
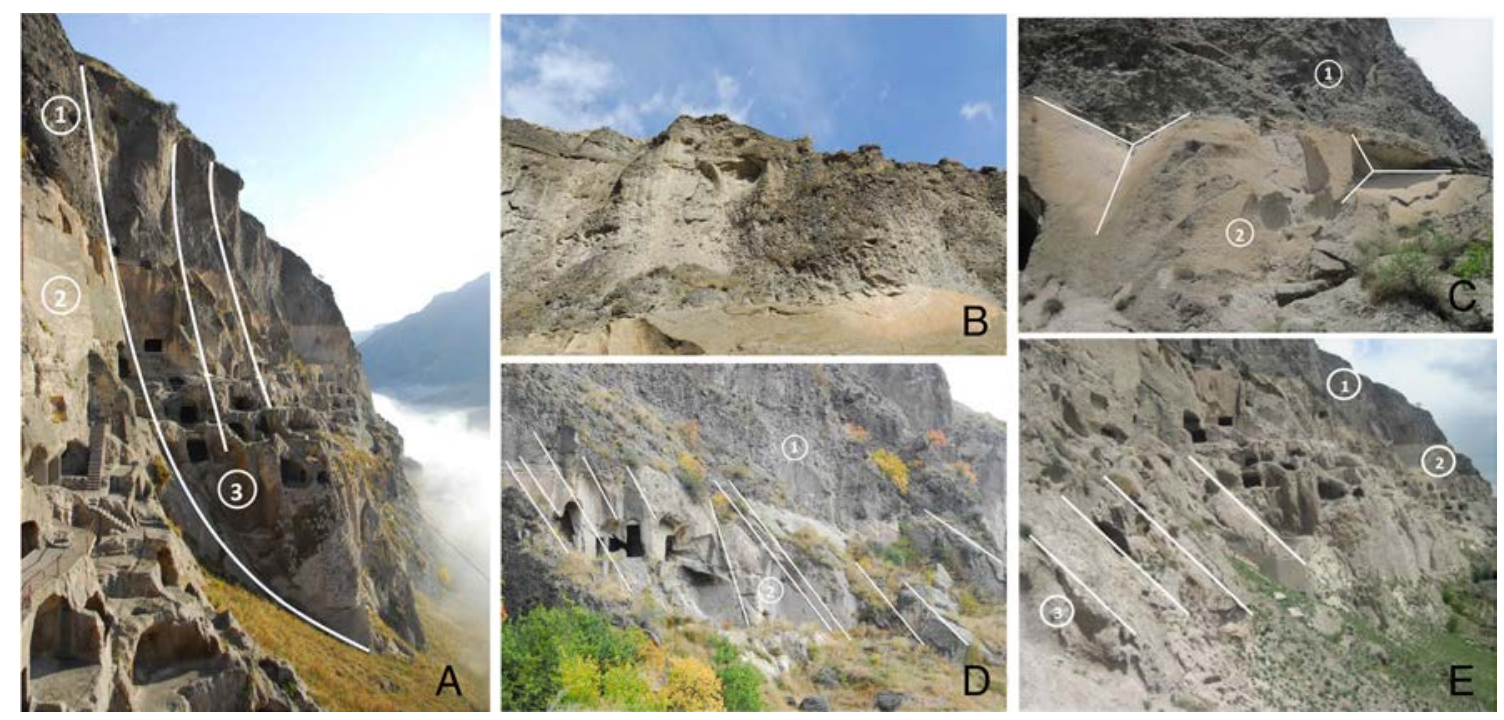

Fig. 6. Slope failure type and processes affecting the rocky cliff of Vardzia. a Large roto-translational rock slide involving both layers 1,2 , and 3 . b Rock fall scarp in the upper part of layer 1 . c Wedge failure at the contact between layer 1 (on top) and layer 2. d High- and low-angle potential planar rock slide. e High- and low-angle potential planar rock slide

In level 1:

a) Large roto-translational rock slide affecting layers 1, 2, and 3 (Fig. 6a) 
b) Rock fall, topple, or wedge failure often due to the lack of support of the underlying layer frequently affected by planar sliding (Fig. 6b)

c) Rock fall of clasts, detached from the matrix of volcaniclastic breccia

In level 2:

d) Wedge failure and rock falling (Fig. 6c)

e) High- and low-angle planar rock sliding along the main discontinuities (Fig. 6d)

In level 3:

f) Planar sliding along the main structural settings (Fig. 6e)

g) Rock fall and topples

Furthermore, widespread superficial erosion morphologies features have been recognized and mapped along the slope. They are mainly due to water runoff and minor stream network able to create slope sediments and small fan delta at the toe of the slope. Depending from the slope angle, alternating erosion, transportation, and deposition of such debris material is occurring.

\section{Monitoring system: preliminary results and future implementation}

\section{Ground-based radar interferometry}

Considering the morphological settings (slope extent ca. $105 \mathrm{~m} 2$ ) and slope instability processes (different typologies in size, magnitude, and probability of occurrence), a new advanced simple and flexible monitoring system has been implemented in order to obtain, namely, measurements, processing, and remote control in real time, and to transform the monitoring system into a warning system. The system adopted for the monitoring of the entire cliff is based on a ground-based interferometric radar (IBIS system from IDS Fig. 7). This equipment allows the monitoring of displacement in the line of sight with a resolution of millimeter. 


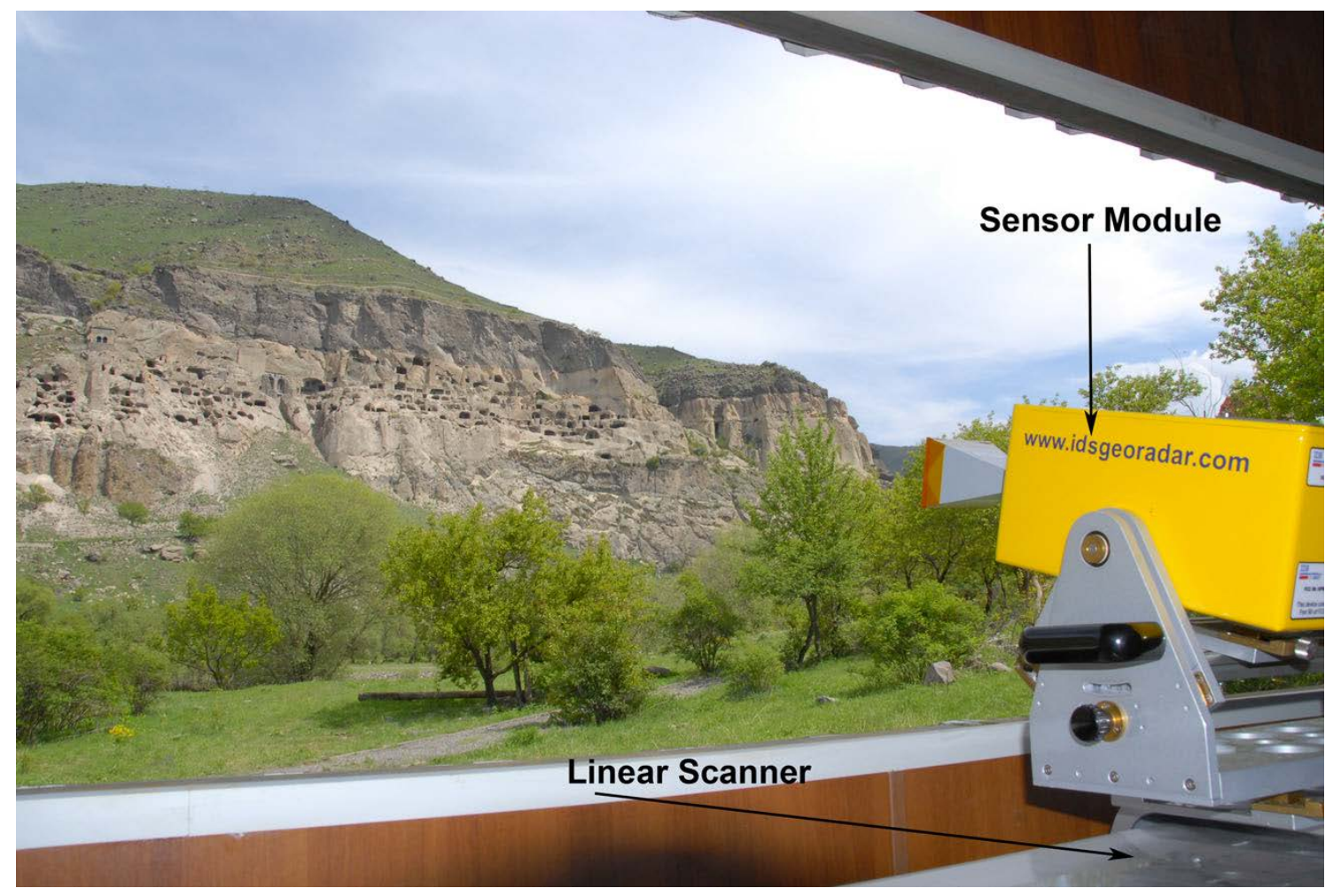

Fig. 7 IBIS-L radar monitoring system $\mathrm{HW}$ description and application in Vardzia

The radar system is a stepped-frequency continuous wave (SFCW) coherent radar with SAR and interfeometric capabilities. The acquisition station has been realized with the valuable support of the NACHPG and the pre-acquisition and start up activities have been finalized and calibrated during the last field mission. The above mentioned technique (SF-CW) allows the resolution of the scenario along range direction independently from the distance (range resolution up to $0.75 \mathrm{~m}$ ). The SAR technique also allows theresolution of the scenario along cross-range direction independently (in the angular value) from the distance (cross-range resolution up to $4.3 \mathrm{mrad}$ ). The differential interferometry technique enables the measure of the displacement of the objects resolved through coupling SFCWanalysis (see Table 2 formain parameters of radar configuration). The system has been installed during the May 2012 field mission. During the period May to October 2012, the system has been initialized and tested. The radar configuration adopted is reported in the following table, the "selection mask" contains about 50,000 points.

The TLS-derived DTM has been used as 3D model for the visualization of the main monitored quantities (displacement and velocity) as collected and stored in real time by the monitoring system.

After the first 6months of monitoring, the preliminary results are quite stable and comfortable. With the exception of some individual control points (mainly due to noise factors related to vegetation), the investigated area is stable and under control (Fig. 8).

The main critical outcomes of the monitoring systems will be carried out along the cliff in order to calibrate and correct the results and define the most active zones in which downscaling of the landslide hazard and risk assessment is recommended. 


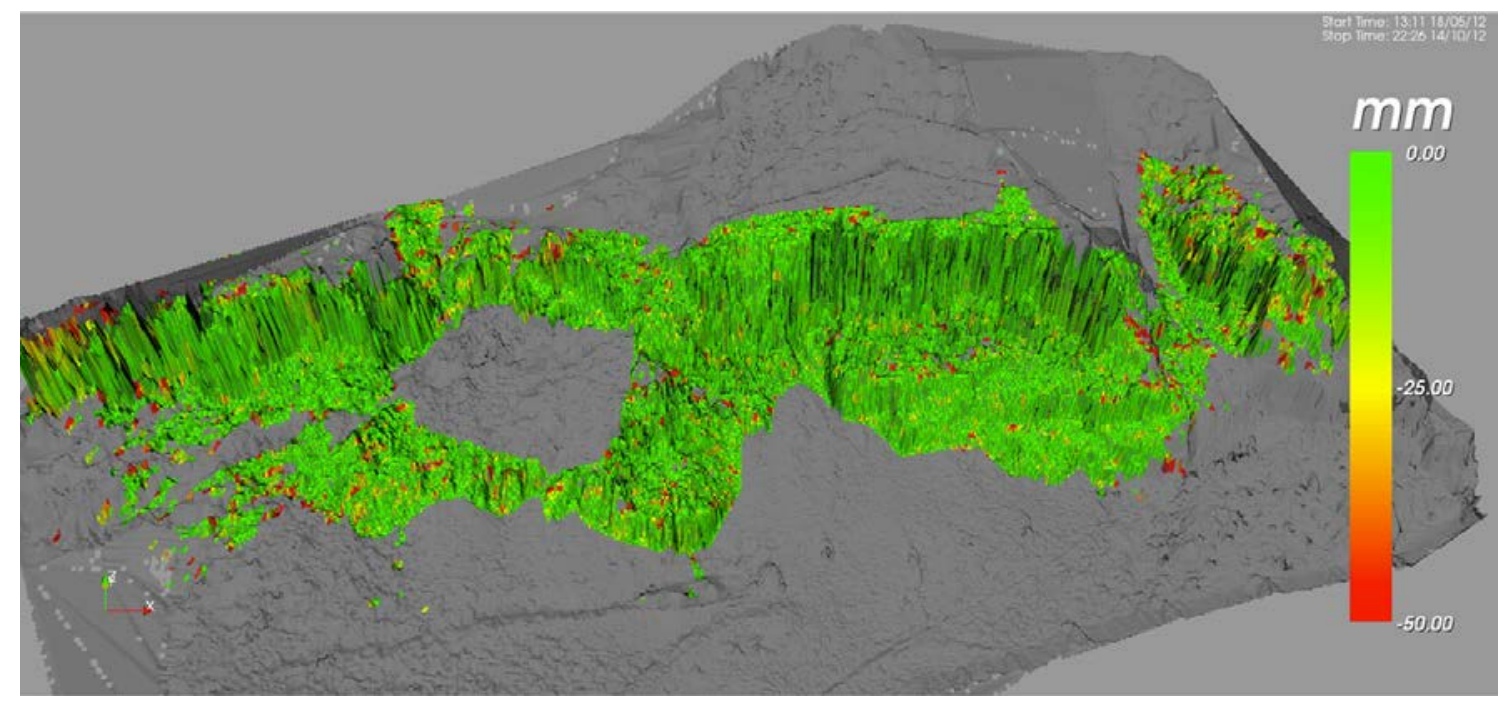

Fig. 8 NAverage velocity and displacements map for the period May to October 2012

\section{Proposed monitoring techniques for rock fall/slide hazard}

The approach to rock fall phenomena with monitoring systems is a challenging issue. In the Vardzia monastery case, the difficulties are enhanced by the necessity to use efficient monitoring methods safeguarding the preservation of the archeological elements. Moreover, as described in previously, this site is affected by different typologies of gravitative processes, which need to be approached with specific monitoring strategies. In this scenario, a two-step approach can be proposed to define an integrated monitoring network. A first phase, which should consider an extensive and low-impact monitoring, aimed at identifying the relevant and most unstable zones. A second phase based on an intensive monitoring in the areas with the highest hazard potential identified in the first phase. For that, regarding the first phase can be considered the integration of different techniques, including the following: (i) GB-SAR to obtain surface displacement and velocity maps (already installed), (ii) TLS and photogrammetric survey to obtain 3D photorealistic models (low-resolution model already available), (iii) installation of a series of thermocouples to detect thermal gradients, and (iv) meteorological parameters monitoring.

For that, regarding intensive monitoring, after the identification of specific unstable areas, can be installed additional thermocouples and moisture sensors together with crackmeters and possibly some borehole extensometers. This equipment should allow for understanding the cyclic thermal and moisture changes and their relationships with slope deformations, especially within the largest rooms located at different depth within the cliff. In fact, weak pyroclastic rocks can undergo strong changes in strength depending on water content, whereas both temperature and moisture could cause rapid weathering of rock surfaces. Borehole extensometers could collect data about the deep deformation within the various layers of the fall deposits and support the slope stability analyses both a local and global cliff scale. In the unstable areas identified, an automated total station could be installed where the displacements cannot be detected by the IBIS radar system in order to improve the resolution of the monitoring system, as integration with the described sensors. The total station provides the measurements of 
two angles (azimuth- zenith) and a slope distance, related to the positions of retroreflective prisms located or even reflector-less points located on the portion of the cliff to be monitored; these measurements can be easily converted in $\mathrm{X}, \mathrm{Y}$, and $\mathrm{Z}$ coordinates referred to a localreference frame. The sensors, fully automated and remotely controlled, allow to detect displacements of millimeter or less, depending on the distance from the station to the monitored points, the atmospheric conditions and the measurement method (prism modality or reflector-less). The total station could be integrated with a GNSS receiver, in order to monitor its stability.

\begin{tabular}{|l|l|l|}
\hline Main parameters & Unit & Value \\
\hline Distance from the slope & $(\mathrm{m})$ & $300-500$ \\
\hline Antenna beam width & $(\mathrm{deg})$ & $>70$ \\
\hline Number of points & -- & 50,000 \\
\hline Range resolution & $(\mathrm{m})$ & 0,5 \\
\hline Cross range resolution & $(\mathrm{mrad})$ & 4,3 \\
\hline Scanning time & $(\mathrm{min})$ & 5 \\
\hline
\end{tabular}

\section{Table 2 Main parameters of radar configuration Main parameters Unit}

\section{Proposed seismic monitoring and micro zoning}

Seismic activity can be extremely relevant to trigger important

rock slides in Vardzia. Earthquake environments could be discussed in terms of two different aspects of occurrences of earthquakes and active faults. Generally, earthquake risk has been based upon the distribution of epicenter of earthquakes that occurred in the past. However, return period of an earthquake in the same zone is the order of a few hundred to several thousand years. Earthquake data based upon the occurrence in the past, even including historical ones, do not cover the possible future earthquakes. If distribution of active faults is known, anticipated earthquake might be selected based upon relative position of the site to causative fault zone and dimension and type of the fault to estimate the most dangerous earthquake to the site.

Recent study on "Seismic Hazard and Risk Assessment for Southern Caucasus-Eastern Turkey Energy Corridors (SHRAP 2009, 2010)” point out some interesting results. Figure 9a shows zonation of seismogenic area in Georgia in the progress report of May 2010. The Vardzia site is found in a zone 17 where the maximum Magnitude is estimated as Mmax $=6.5$ of expected. Figure 9b represent the seismotectonic map of Georgia from the progress report of SHRAP (2009), where active faults are identified and shown in red line. Vardzia is found just on a fault line extending from south-west to north-east with length of about $50 \mathrm{~km}$.

Two kinds of earthquakes shall be selected as most probable earthquake that occurs within 50-100 years and the most dangerous earthquakes to the site based upon occurrences of earthquakes in the past and active faults. Based upon these two levels of earthquakes, design ground motions shall be obtained to be used for the study of stability of slopes and safety of caves by dynamic simulation as input ground motions.

SHRAP (2009). The site of Vardzia is added as a blue spot. Estimated epicenters of some historical earthquakes of magnitude 5.5-6.5 and 6.5- 7 are found within the 
distance of near field $10 \mathrm{~km}$ from the Vardzia. The instrumented record (later than 1962) also gives some distribution of epicenters of earthquakes with mag. 3.5-4.5 within $10 \mathrm{~km}$ from the Vardzia. The near field region from an earthquake will produce direct and strong ground motion at the site. Since the earthquake is one of thepotential factors to cause failure of slopes as well as damage of cave structure, it is strongly recommended to install seismic monitoring station. Two different types of recording system are useful. One is strong ground motion recording system. Figure 9c shows Modern Digital Seismic Network of Georgia (Elashvili and Javakhishvili 2004). Planned station VRZ is shown in the map. Another one is rather for weak ground motion including micro-tremor. 

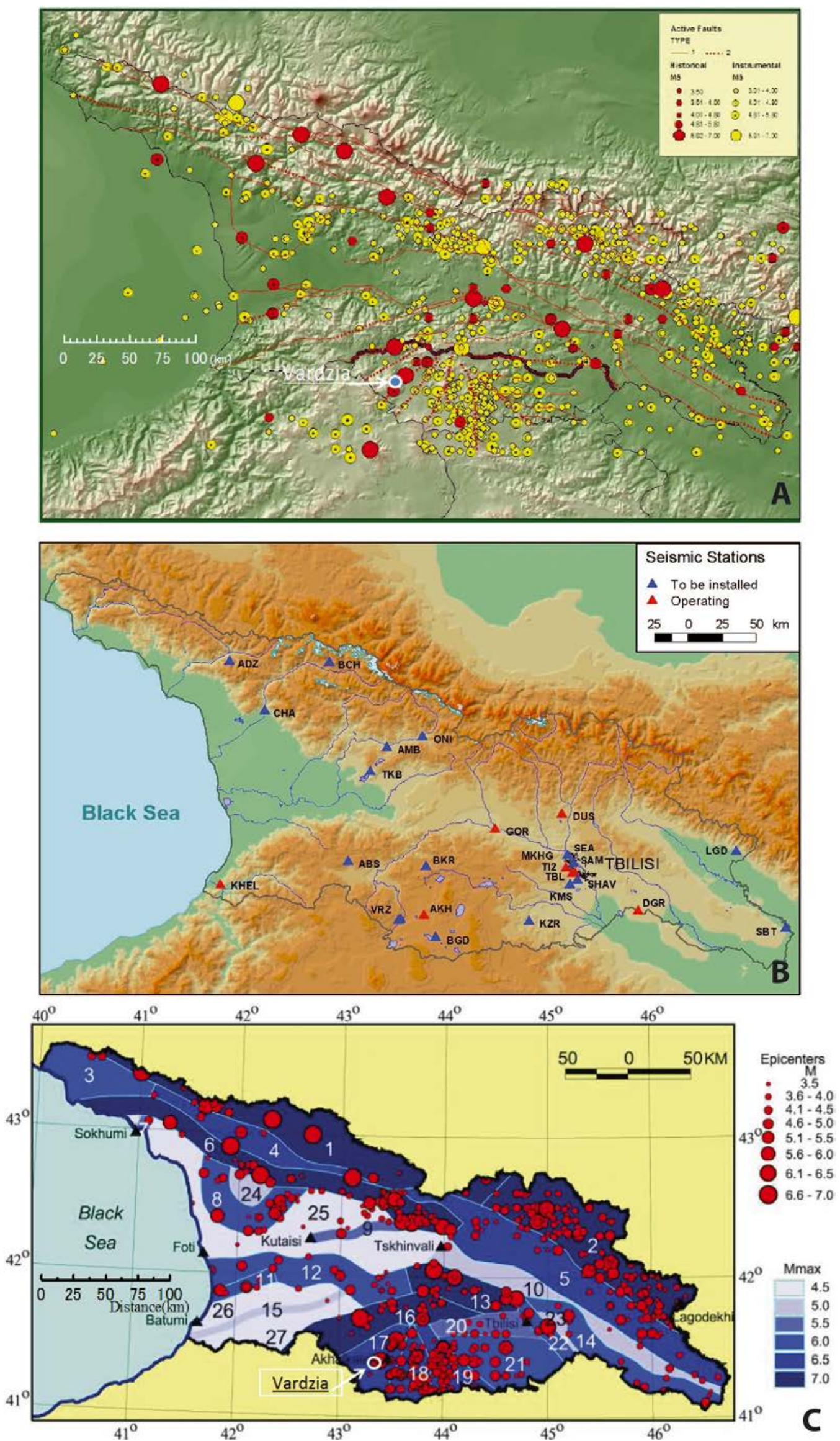
Fig. 9 Seismicity of Georgia. a Seismic area zoning (SHRAP 2010). b Seismotectonic map (Mw > 3.5) with red lines showing active faults (SHRAP 2009). c Planned seismic net work in Georgia (Elashvili and Javakhishvili 2004)

The reason of monitoring weak ground motion by small earthquakes with short distance and by big earthquakes with long distance is that the recorded ground motion contains various basic dynamic characteristics of the site with more chance of obtaining records than strong motions. Micro-tremor is a low-amplitude (in the order of micrometers) ambient vibration of the ground caused by man-made or atmospheric disturbances. Micro-tremors at such points on the slope as identified as moved by the radar scanning system shown in Fig. 7 could provide dynamic characteristics of the point. Amplitudes and loci of micro-tremors as well as frequency characteristics like predominant period of vibration are useful index to analyze stability trend of these trends.

Finally, velocities of P and S waves are basic physical coefficients of rocks. Small-scale refraction survey with vibration source by hammering at different rock types on rock surface as well as in the caves provides dynamic parameters of each rock without any damage to the site. The changing and variation of these velocities in the same rock layer as well as different types of rock could provide degree of weathering and existence and densities of cracks. The obtained values are vital and necessary parameters for any dynamic analysis

\section{Future conservation strategies}

\section{$\underline{\text { Stability model and complete landslide hazard and risk assessment proposal }}$}

The occurrence of both small-size rockfall events (including topples and wedges) and block slides constitutes themain threats for the site and its visitors. Listric joints develop parallel to the slope face and define potentially unstable rock blocks of different shapes and magnitudes (Figs. 5 and 6). Most of the joints display dip angles greater than $60^{\circ}$, which are kinematically unstable. Failure is initially prevented because the listric joints are not fully persistent and their continuity is reduced by the presence of rock bridges (Fig. 10). Rock bridges separating joint segments and fractures provide and effective cohesion to the joint, and the rock block cannot fall or slide until the bridge fail. 


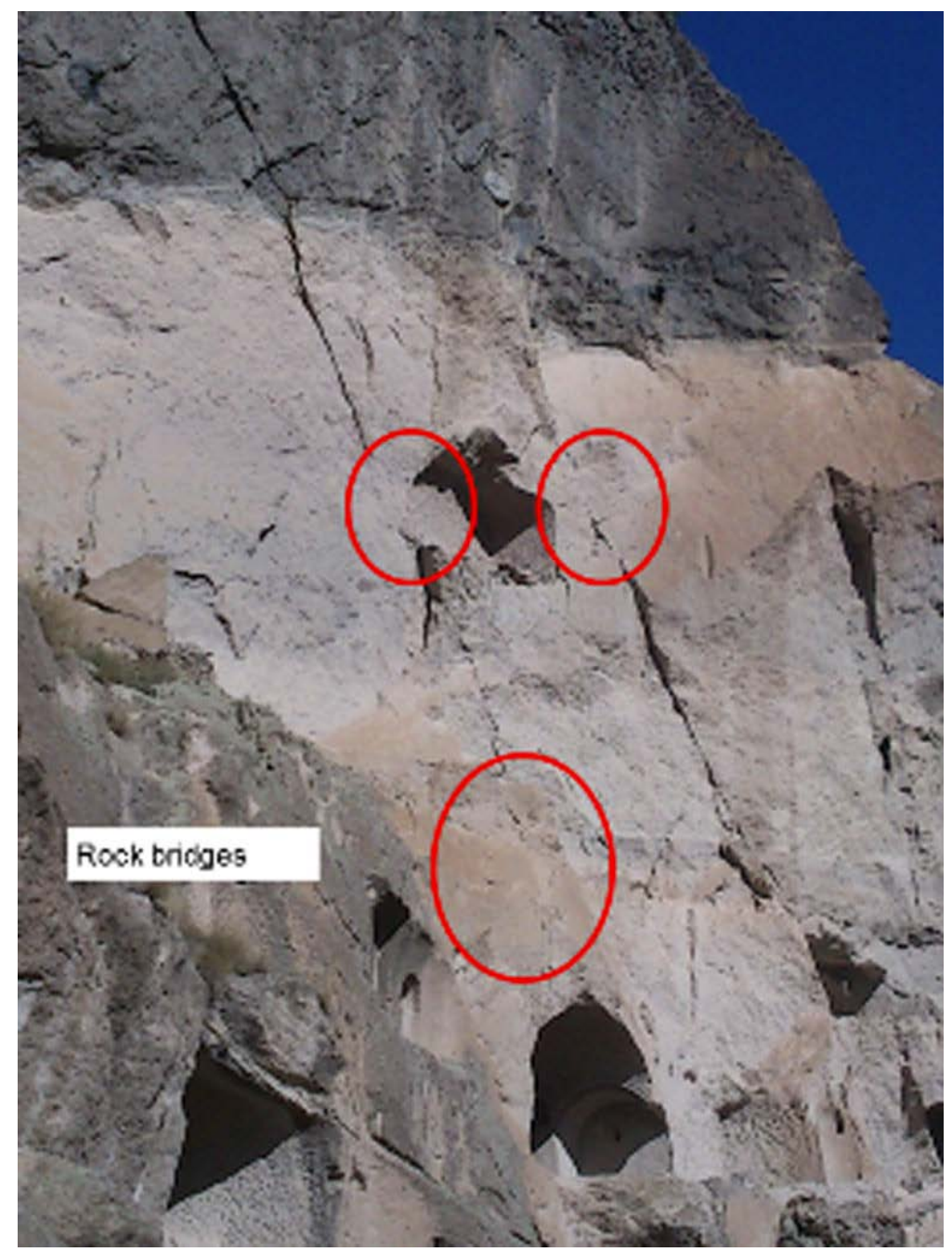

Fig. 10 Rock bridges in joints affecting massive lapilli tuff (layer 2 of Fig. 4)

Evaluating the strength of the rock bridges is fundamental for the assessment of the hazard potential and associated risk. The rock mass is assumed to fail in shear and tension while provides a strength component proportional to the fraction of the failure plane that is still intact (Jennings 1970). The importance of rock bridges on the stability of rock slopes has been addressed among others by Einstein et al. (1983) and Nichol et al. (2002).

Failure in non-fully persistent (intermittent) joints may take place along a single surface, or a step-path surface, or through intact rock. The strength $(\tau)$ along the plane of the listric joints may be expressed by the following equation (Jennings 1970):

$\mathrm{t}=\mathrm{k} \cdot \square\left(\mathrm{c}_{\mathrm{j}}+\sigma_{\mathrm{n}} \tan \Phi_{\mathrm{j}}\right)+(1-\mathrm{k})^{\cdot}\left(\mathrm{c}_{\mathrm{i}}+\sigma \mathrm{ftan} \Phi_{\mathrm{i}}\right)$

where $\mathrm{cj}$ is the cohesion intercept of the joint segment, $\Phi \mathrm{j}$ is the friction angle of the joint segment, ci is the cohesion intercept of the rock bridge, $\Phi \mathrm{i}$ is the friction angle of the intact rock, $\sigma \mathrm{n}$ is the normal stress uniformly distributed between the joint segment and the rock bridge, and $\mathrm{k}=\mathrm{lj} /(\mathrm{lj}+\mathrm{li})$ is the ratio of joint segment over the total length. Another possibility is to resort to a fracture mechanics approach. In this case joints are 
considered as fractures, which can propagate into the rock bridges, both in mode I (tensile stresses) and in mode II (shear stresses). The propagation of the joints can be assessed using a propagation criterion on the basis of the rock toughness value. Numerical codes have been developed (Scavia 1995) to evaluate the possibility for a rock volume to fail on the basis of the simulation of joint propagation into the rock cliff. The stability analysis has account for the seismic effect as well. As it has been already mentioned, in $1283 \mathrm{AD}$, an earthquake destroyed approximately two thirds of the city and collapsed the irrigation system (Gaprindashvili 1975). Historically up to 6.5-7 earthquake magnitudes have been observed within the distance of $10 \mathrm{~km}$ from the Vardzia. A pseudo-static limit equilibrium analysis is recommended for each potential block slide identify along the cliff, whereby the destabilizing effect of an earthquake is represented by a horizontal force. The value of this force has to be calculated considering the expected peak ground acceleration (PGA). To account for the topographic amplification, the PGA will be increased by linear interpolation between the base and the top of the cliff, following the methodology developed by Mavrouli et al. (2009). The geometry of each potentially unstable rock block has to be determined based on field surveys of the rock mass. Scan-lines combined with high-resolution photos are going to be used to quantify the extent of rock bridges. Joint persistence is the most difficult parameter to obtain because direct mapping of discontinuities internal to a rock mass is not possible unless the failure has occurred and plane is already exposed. The latter case will be used for back-analysis. Individual rock blocks might be bounded for more than one kinematically unstable joint. In such a case, the stability analysis has to be performed for both geometries. Measures of the in situ cliff displacements provided by the GBSAR will provide a complete view of the on-going instability process in the rock face and will confirm the boundaries and size of the unstable rock block. At the same time, it may become a preliminary early warning system. At the same time, there are sufficient evidences to support the possibility of deep failures as occurred and witnessed during the $1283 \mathrm{AD}$ earthquake. The available detailed topographic surveys of the rocky cliff and of the rooms and cavities excavated within the slope could allow the reconstruction of a fully 3D numerical model. This model could be used as a tool in order to: (i) identify most stressed points (e.g., pillars, vaults, walls) to be reinforced or protected, (ii) effect of possible reinforcements to be designed and implemented, (iii) extent of possible local and generalized failures under both static and dynamic conditions. Therefore, it is suggested to perform a fully 3D FEM/FDM modeling of the entire slope.

TLS points cloud could be used to identify single unstable blocks and to characterize them according to their geometry and position along the cliff, as well as to detect the most critical rock mass sectors by means of detailed true 3D kinematic analyses, by assigning different weights to the discontinuities (either semiautomatically extracted from TLS data or measured in situ) based on their true position on the investigated rock mass (Abellán et al. 2010; Gigli and Casagli 2011). This information is mandatory for a reliable rock fall modeling which could be performed through a 3D numerical code. In fact, local cliff orientation, presence of small benches (cliff paths between rooms), and the complex geometry of the talus and lower rocky slopes could force blocks to follow anomalous trajectories (Crosta and Agliardi 2003, 2004; Agliardi and Crosta 2003). The Hy-Stone rockfall code (Crosta and Agliardi 2004) could allow to carry out a detailed and robust modeling of rockfall phenomena and to accomplish a reliable hazard and risk modeling (Frattini et al. 2008; Agliardi et al. 2009) starting from all the available information and testing for different scenarios (block size, detachment position, block 
physical mechanical characteristics). In fact, the exposure of visitors along the approaching road and paths as well as along the cliff is high over very large areas an remedial mitigation works are required to guarantee a sufficient safety margin. In fact, the proposed Hy-Stone code is able to include the effects of passive countermeasures (e.g. catch nets, embankments, ditches) or of natural obstacles (e.g. vegetation) as well as of secondary trajectories deriving from block fragmentation (i.e. explosion at impact points).

\section{$\underline{\text { Risk mitigation policies and sustainability }}$}

Up to now, no major mitigation strategies were implemented in Vardzia. Few bolts were locally installed, buttress and wall structures were executed in collapsed areas to prevent further degradation, the mid-level pedestrian path was partially reconstructed, and a manual crack gauge monitoring was operating in the period 1968-1979. Cliff instability mitigation measures usually require the use of either structural or non-structural measures, or a combination of both. Structural measures imply intensive earthwork and the construction of concrete structures (VanDine 1996) and may be visually intrusive. Design of stabilization and protection works of the Vardzia cliff have the challenge of reconciling safety and conservation of the site with sustainability and visual integration. Surface reinforcement techniques can be used to prevent small-size rock wedges and blocks to produce rockfalls. They aim at providing surface reinforcement and restrict loosening of the rock mass. High-strength masses that are low visually intrusive can be considered usually combined with nails or rock bolts to fix them to the rock surface (Corominas 2013). Stabilization elements have to be carefully selected. Volcanic rocks in which the caves have been excavated are highly weatherable materials that experience fast surface deterioration, raveling, and spalling (Fig. 11). Because of this, some measures may become inefficient. The chemical nature of the lapilli and pumice has to be determined in order use compatible products. Results from the mathematical models (slope stability and rock fall scenarios), combined with seismic activity analysis and historical rockfall database analysis, will allow to reach a complete description of future possible failure scenarios and to propose susceptibility and hazard zoning, up to a risk assessment for exposed people and structures. This analysis will also support the choice and design of risk mitigation countermeasures to be installed for a safe exploitation of the historical site. The main focus of the adopted solutions will be the low environmental impact, to enhance the importance of sustainable solutions, especially when dealing with cultural heritages. 


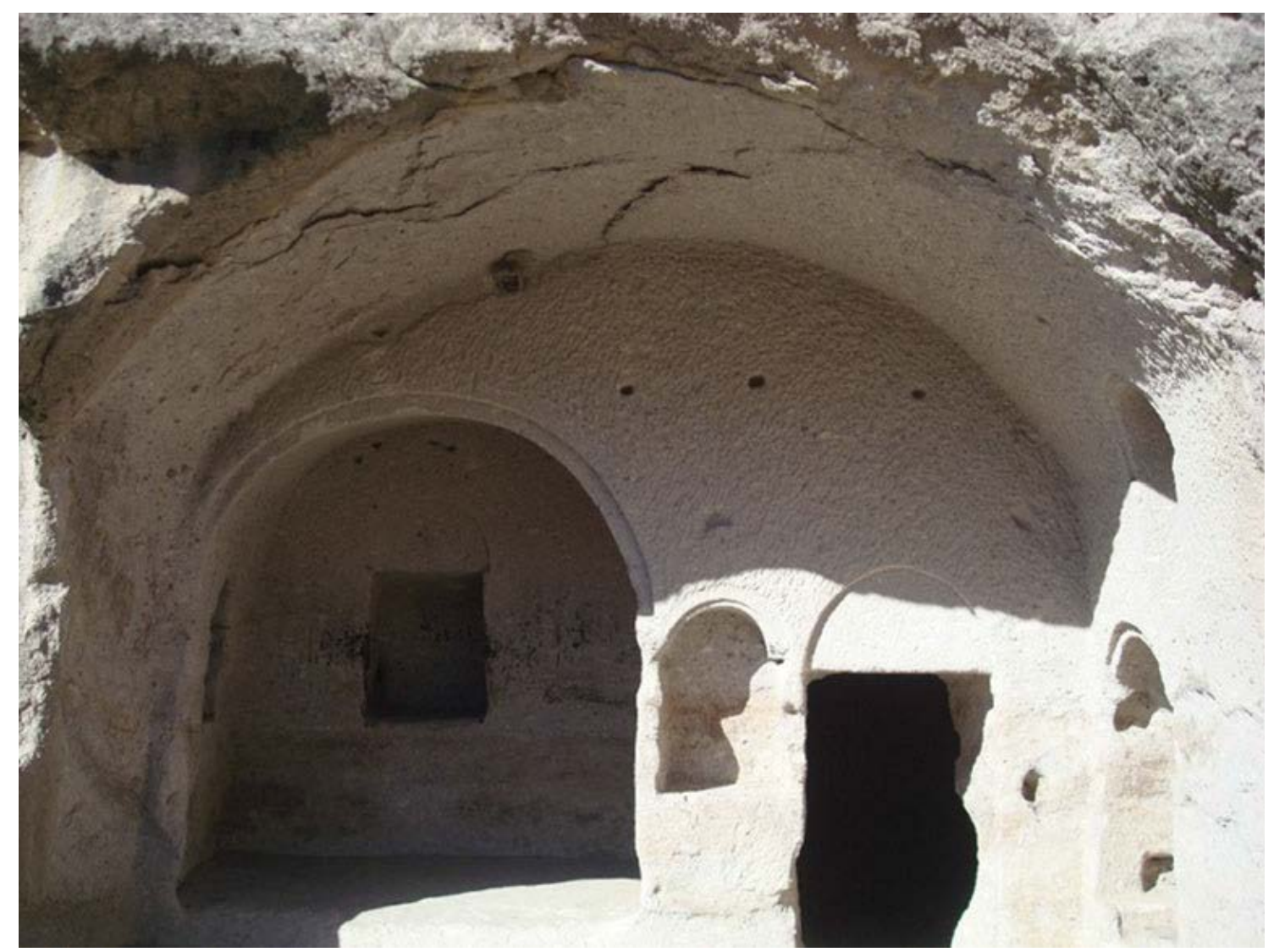

Fig. 11 Spalling of the rock surface in the roof of the room, controlled by rock weathering and stress degradation

\section{Conclusions}

According to the present study and field missions, predominant and more frequent geomorphological processes in Vardzia are, from the top of the cliff and with reference to Fig. 4, as follows:

1. Erosion and water run-off on the catchment above site. These phenomena may cause small rock-stone fall, during heavy rainfall. Limited slope sediments and small fan delta have been recognized at the toe of the slope.

2. In the upper black volcanoclastic breccia (level 1 in Fig. 4), there are mainly rock fall of clasts, detaching from the matrix. Tourists are themost exposed to these phenomena. Occasionally, topple or wedge failure can be recognized, often due to the lack of support of the underlying layer, frequently affected by planar sliding.

3. In the light clear massive lapilli-tuff (level 2 in Fig. 4), the main rock slope failure are mainly due to wedge failure and rock falling and high- and low-angle planar rock sliding along the main discontinuities.

4. In the clear lapilli-tuff with dark pumicies, scorias, and bombs (level 3 in Fig. 4), the main observed and potential rock slope failures are planar sliding along the main structural settings and topples.

5. Large roto-translational rock slide are occasional affecting layers 1,2 , and 3 , and may be during strong earthquakes. 
Items 1 and 2 may mainly involve tourists in their evolution where items 3, 4, and 5 are mainly relevant for the conservation of cultural heritages.

As a consequence of the above, also considering that the potential instability processes and mechanisms observed for the entire rock cliff can be referred to different failure modes (or their combination) and differ along the whole cliff in terms of activity, their state (temporal evolution), distribution (spatial evolution), style (combination and repetition of different failure mechanism), and magnitude (landslide intensity and potential volumes), future investigations will require the following:

1. A better understanding of the role and combination of different predisposing factors such as the following: lithology, presence, frequency and orientation of discontinuities vs. slope orientation physical and mechanical characteristics of materials, moisture, and morphological and hydrological boundary conditions.

2. A better understanding of triggering factors, such as, among the many potential, seismicity, thermal effects, rain infiltration, and run-off, for the variety of identified phenomena 3. More accurate and specific analysis for some of the detected potential instability conditions (slope scale risk analysis) in order to define failure state in terms of intensity, potential evolution, and impact

4. The coupling of different survey techniques (e.g., 3D laser scanner, engineering geological and geomechanical field surveys, ground-based radar interferometry), to be adopted in the interdisciplinary field of cultural heritage protection and conservation policies

5. The maintaining and analysis of real time monitoring system, suitable for the specific site conditions being able to account

for all the abovementioned site peculiarities 6 . The implementation of a local seismic network and the investigation of local seismic response and amplification

Finally, a mitigation project addressed to evaluate and mitigate risk associated to slope failure will be implemented, for both shortand long-term actions. This will emphasize the low environmental impact of adopted solutions, as fundamental management tool to prepare a master plan for a safe and sustainable future tourist exploitation of the historical site.

\section{Acknowledgments}

This paper has been developed within the activities of the International Consortium of Landslides, network on "Landslides and Cultural \& Natural Heritage (LACUNHEN)". The authors are very grateful to all the National Agency for CulturalHeritage Preservation of Georgia staff members for their support and continuous help.

\section{References}

Abellán A, Calvet J, Vilaplana JM, Blanchard J (2010) Detection and spatial prediction of rockfalls by means of terrestrial laser scanner monitoring. Geomorphology 119:162-

171

Agliardi F, Crosta G (2003) High resolution three-dimensional numerical modelling of rockfalls. Int J Rock Mech Min Scie 40(4):455-471 
Agliardi F, Crosta GB, Frattini P (2009) Integrating rockfall risk assessment and countermeasure design by 3D modelling techniques. Nat Hazards Earth Syst Sci 9:1059-1073

Baldo M, Bicocchi C, Chiocchini U, Giordan D, Lollino G (2009) LIDAR monitoring of mass wasting processes: the Radicofani landslide, Province of Siena, Central Italy. Gemorphology 105:193-201

Barton NR (1973) Review of a new shear-strength criterion for rock joints. Eng Geol

7:287-332

Binal A (2009) Prediction of mechanical properties of non-welded and moderately

welded ignimbrite using physical properties, ultrasonic pulse velocity, and point load index tests. Q J Eng Geol Hydrogeol 42:107-122

Cruden DM (1991) A simple definition of a landslide. Bull Int Assoc Eng Geol 43:2729

Cruden DM, Varnes DJ (1996) Landslide types and processes. In: A.K. Turner, R.L. Schuster (eds.) Landslides investigation and mitigation (Special report 247, pp. 3675). Transportation Research Board, Washington, D.C

Corominas J (2013) Avoidance and protection measures. In: Shroder JF (ed) Treatise on Geomorphology, vol 7. Academic Press, San Diego, pp 259-272

Crosta GB, Agliardi F (2003) A new methodology for physically-based rockfall hazard assessment. Nat Hazards Earth Syst Sci 3:407-422

Crosta GB, Agliardi F (2004) Parametric evaluation of 3D dispersion of rockfall trajectories. Nat Hazards Earth Syst Sci 4:583-598

Del Potro R, Hürlimann M (2009) The decrease in the shear strength of volcanic materials with argillic hydrothermal alteration, insights from the summit region of Teide stratovolcano, Tenerife. Eng Geol 104:135-143

Einstein HH, Veneziano D, Baecher G, O’Reilly K (1983) The effect of discontinuity persistence on rock slope stability. Int J Rock Mech Min Sci Geomech Abstr 20:227-236

Elashvili M, Javakhishvili Z (2004) http://www.fdsn.org/meetings/2004/ Georgia_FDSN_2004.pdf

Ershov AV, Brunet MF, Korotaev MV, Nikishin AM, Bolotov SN (1999) Late Cenozoic burial history and dynamics of the Northern Caucasusmolasse basin: implication for foreland basin modeling. Tectonophysics 313:219-241

Frattini P, Crosta GB, Carrara A, Agliardi F (2008) Assessment of rockfall susceptibility by integrating statistical and physically-based approaches. Geomorphology 94:419-437. doi:10.1016/j.geomorph.2006.10.037

Gamkrelidze IP (1986) Geodynamic evolution of the Caucasian and adjacent areas in

Alpine time. In: Zoneshain LP (Ed.), Tectonics of the Eurasian Fold Belts. Tectonophysics 127, 261-277

Gaprindashvili G (1975) (in English, Russian, Georgian) Ancient monuments of Georgia: Vardzia. Aurora Art Publishers, Leningrad, pp 7-25. ISBN 978-1-13568320-7

Gigli G, Casagli N (2011) Semi-automatic extraction of rock mass structural data from high resolution LIDAR point clouds. Int J Rock Mech Min Sci 48:187-198

Gillespie MR, Styles MT (1999) BGS ROCK Classification Scheme Volume 1

Classification of Igneous Rocks. British Geological Survey Research Reports

(2nd edition) RR 99-06

Gudjabidze GE, Gamkrelidze IP (2003) Geological Map of Georgia, 1:500.000. Georgian State Department of Geology and National Oil Company "Saqnavtobi”

Hoek E (2007) Practical Rock Engineering (2007 edition) http://www.rocscience.com 
ISRM - Commission on Standardization of Laboratory and Field Tests (1978) Suggested methods for the quantitative description of discontinuities in rock masses. Int. Journ. Rock Mech. Min. Sci. \& Geomech. Abstracts 15, n.6, 319-368

ISRM- Commission on Classification of Rocks and Rock Masses (1981) - Basic geotechnical description of rock masses. Int. Journ. Rock Mech. Min. Sci. \& Geomech. Abstracts 18, 85-110

Jennings JE (1970) A mathematical theory for the calculation of the stability of open cast mines. Proc. Symposium on the Theoretical background to the Planning of Open Pit Mines. Johannesburg. pp. 87-102

Lembo Fazio A, Manfredini G, Ribacchi R, Sciotti M (1984) Slope failures and cliff instability in the Orvieto hill. 4th Int. Symp. on Landslides, Toronto, 2, 115-120

Margottini C, Marsella M, Orlando L, Pandolfi O, Soddu P, Sonnessa A, Spizzichino D, Delmonaco G, Cardareli G, De Donno G (2009) Low impact investigation techniques for parameterization and conservation of Cultural Heritage: the case study of Moai statues at Easter Island (Chile). Geoitalia 2009 - sesto forum italiano di scienze della terra, Rimini 09-11 settembre

Margottini C, Spizzichino D (2009) The management of cultural and environmental heritage sites: a pivot for conservation and enhancement. Proceedings of the first International Symposium on Danxia Landform. The 2nd collection. Danxiashan, Guadong (China), 26-28 May, 2009

Margottini C, Spizzichino D (2014) How geology shapes human settlements. In Bandarin F. \& van Oers R. (eds.), Reconnecting the city. The Historic Urban Landscape Approach and the Future of Urban Heritage. Chichester: Wiley Blackwell

Mavrouli O, Corominas J, Wartman J (2009) Methodology to evaluate rock slope stability under seismic conditions at Solá de Santa Coloma. Andorra Nat Hazards Earth Syst Sci 9:1763-1773

Mitchell J, Westaway R (1999) Chronology of Neogene and Quaternary uplift and magmatism in the Caucasus: con-straints from K-Ar dating of volcanism in Armenia. Tectonophysics 304:157-186

Moon VG (1993) Microstructural controls on the geomechanical behavior of ignimbrite. Eng Geol 35:19-31

Nichol SL, Hungr O, Evans SG (2002) Large-scale brittle and ductile toppling of rock slopes. Can Geotech J 39:773-788

Tuğrul A (2004) The effect of weathering on pore geometry and compressive strength of selected rock types from Turkey. Eng Geol 75:215-227

Pola A, Crosta G, Fusi N, Barberini V, Norini G (2012) Influence of alteration on physical properties of volcanic rocks. Tectonophysics 566-567:67-86

Rodríguez-Losada JA, Hernández-Gutiérrez LE, Olalla C, Perucho A, Serrano A, EffDarwich A (2009) Geomechanical parameters of intact rocks and rock masses from the Canary Islands: implications on their flank stability. J Volcanol Geotherm Res 182:67-75

SHRAP (2009) APRIL Progress Report - 2009, Seismic Hazard and Risk Assessment for Southern Caucasus-Eastern Turkey Energy Corridors (SHRAP) http:// www.koeri.boun.edu.tr/depremmuh/eski/nato/project/pdf/progress1_983038.pdf

SHRAP (2010) MAY Progress Report - 2010, Seismic Hazard and Risk Assessment for Southern Caucasus-Eastern Turkey Energy Corridors (SHRAP) http:// www.koeri.boun.edu.tr/depremmuh/eski/nato/project/pdf/progress3_983038.pdf

Scavia C (1995) A method for the study of crack propagation in rock structures, Géotecnique, 45, No 3, 447-463, The institution of civil engineers, London 
Spizzichino D, Delmonaco G, Margottini C (2009) Geo-structural modelling for potential large rock slide in Machu Picchu- European Geosciences Union 2009 General Assembly, Vienna Austria, 19-24 April

Turner AK, Schuster RL (1996) Landslides investigation and mitigation (Special report 247) Transportation Re-search Board: Washington D.C., pp. 673

WP/WLI (1993) A suggested method for describing the activity of a landslide. Bull Int Assoc Eng Geol 47:53-57

VanDine DF (1996) Debris flow control structures for forest engineering: British Columbia Ministry of Forests Research Program, Victoria, B.C., Working Paper 08/1996. www.for.gov.bc.ca/hfd/pubs/Docs/Wp/Wp22.htm. Accessed 12 Nov 2009 